\title{
FITNESZSZOLGÁLTATÓK MARKETINGTEVÉKENYSÉGE AZ ÉSZAK-ALFÖLD RÉGIÓBAN
}

\author{
Müller Anetta - Gabnai Zoltán - Bácsné Bába Éva - Pfau Christa Sára - \\ Bartha Éva Judit - Molnár Anikó - Pető Károly
}

\section{Összefoglalás}

A fitneszszolgáltatások alkalmasak a mozgásszegény életmód kompenzálására, ezért napjainkban megnövekedtek az ezek keresletét, fogyasztói motivációját elemzö irások. A kinálat is kutatott terület, ahol elsösorban a szolgáltatás minöségével kapcsolatban vizsgálódtak a kutatók. Kevés kutatás ír a fitnesztermeket üzemeltetö cégek vállalkozási tevékenységéröl. Kutatásunkban az Észak-Alföld régióban müködö fitneszszolgáltatásokat nyújtó vállalkozások $(N=31)$ vállalkozási tevékenységének feltérképezésére vállalkozunk. Jelen tanulmányban azt mutatjuk be, hogy a fitnesztermek üzemeltetöi mennyire vélik fontosnak a marketingmix elemeinek tudatos alkalmazását. Az eredmények igazolják, hogy a szolgáltatók követik a trendeket, melyeket megjelenitenek a termékfejlesztésben. Így a trendekhez igazitott kinálatfejlesztés a szolgáltatók marketingtevékenységének egyik meghatározó eleme. A kinálat kialakitásakor a szolgáltatók olyan kiegészitö szolgáltatásokat (pl. wellnesskinálati elemek) is megcéloznak, melyek hatékony módon egészitik ki a különbözö edzésformákat, egyben biztositják a regenerációt. A szolgáltatásfejlesztés a változó igényeknek való megfelelésre, az egyediségre való törekvésre is fókuszál, amely piaci elönyt eredményezhet, hozzájárulva a versenyképesség növeléséhez. Arképzésükre az árelfogadó stratégia és a versenytársakhoz igazitott árképzés a jellemző. Promóciós tevékenységükben és az értékesitésben elönyben részesitik az onlinemarketing-eszközöket.

Kulcsszavak: fitneszszolgáltatók, trendek, marketingmix, termékfejlesztés, fizikai aktivitás

JEL: M31, L83 


\title{
MARKETING ACTIVITIES OF FITNESS SERVICE PROVIDERS IN THE NORTHERN GREAT PLAIN REGION
}

\begin{abstract}
As fitness services are suitable for compensate the disadvantageous effects of sedentary lifestyle, the number of studies which focus on the sport services' demand and consumer motivation has significantly increased. Supply is also an area worth exploring, accordingly researchers conducted research studies primarily connected to the quality of service. Relatively few researches were focused on investigating the activities and characteristics of companies that operate fitness centers. Therefore, in our research we undertake the mapping of the entrepreneurial activity of companies providing fitness services in the Northern Great Plain region $(N=31)$. This study demonstrates that how important is the conscious use of marketingmix elements by service providers. Our results prove that the providers follow fitness trends and use the related information during product development. Thus, trend-oriented supply development is a key element in their marketing activities. Besides providing basic services, they also focus on complementary services (e.g. wellness facilities), which complement various workouts effectively. In addition to responding to changing consumer needs, service development often involves the pursuit of uniqueness. Their pricing is based on the strategy of adopting prices and competitororiented pricing. In terms of their promotional activities and sales channels, they prefer modern sales opportunities, especially online marketing to traditional tools and places.
\end{abstract}

Keywords: fitness providers, trends, marketing mix, product development, physical activity

JEL: M31, L83 


\section{Bevezetés}

Napjainkban a fejlett és fejlődő országokban is megemlíthető az a tendencia, mely szerint - döntően a tercier szektor, vagyis a kereskedelmi, szolgáltatási tevékenységek és a technológiai fejlődés okán - a munkahelyen ülő testhelyzetben eltöltött idő jelentősen megnőtt. Ez az ülő életmód fokozatos kialakulásához és a fizikai inaktivitás szintjének növekedéséhez vezetett. Ennek kompenzálása céljából egyre többen választják a szabadidős sportolás, testmozgás valamilyen formáját. Az Eurobarométer 2018-as felmérése alapján Európában a felnőttek 7\%-a rendszeresen, heti 5-ször vagy annál is nagyobb gyakorisággal, 33\%-uk valamilyen rendszerességgel (heti 1-4 alkalommal), 14\%-uk ritkán sportolt. Igen magas, 46\%-os volt azok aránya azoknak, akik soha nem végeznek szabadidősportot. A vizsgálatból az is kiderül, hogy melyek a szabadidős sportolás kedveltebb helyszínei. A rekreációs sporttevékenységet űzők 40\%-a a szabadban, 32\%-a az otthonában, másik 32\%-a a munkába vagy iskolába menet szeret sportolni. A térítés ellenében igénybe vehető szabadidős sportszolgáltatásokat az európai lakosok 12\%-a sportklubokban, 15\%-uk egészség- vagy fitneszközpontokban veszi igénybe (Eurobarométer, 2018). A fitneszszolgáltatók előnye származhat abból, hogy a felszereltségük kiválóan alkalmas arra, hogy az egészség szempontjából fontos alap-állóképességet és a fizikai fittséget az egyes izomcsoportok erejét fejlesztő gépekkel növelni tudják. A fitnesztermek mint sportszolgáltatók előtérbe kerülésével egyre fontosabb kérdésként jelenik meg a szolgáltatást kísérő marketingtevékenységek tudományos igényű vizsgálata.

\section{Szakirodalmi áttekintés}

\section{A fitnesz szektor fellendülése}

A szabadidő eltöltésében az aktív programok, szabadidősportok egyre fontosabb szerepet játszanak, melyek a mozgásszegény életmód kompenzálásának eszközévé váltak. A szabadidő- és a tömegsport mind társadalmi, mind gazdasági szempontból egyre nagyobb jelentőséggel bír (Nagy-Tobak, 2015). A szabadidősportot üzők fogyasztói szokásait érintő trendek (Molnár, 2019; Lenténé et al., 2018a; Horkay et al., 2018.; Gődény et al., 2018; Lengyel, 2016; Nagy-Tobak, 2014; Bíró-Müller, 2017; Thompson, 2016, 2017, 2020) azt igazolják, hogy azok a sport- és fitneszszolgáltatások a népszerủek, melyek alkalmasak a fizikai fittség javítására és az alakformálásra, továbbá elősegítik a kardiorespiratorikus állóképesség fejlesztését és a fogyást, emellett a mozgatórendszer funkciójának javítását is biztosítják (Lenténé et al., 2019). Az ilyen funkcionális tréningek hozzájárulnak a mindennapi tevékenységek sikeres el- 
végzéséhez, a munkabírás növeléséhez, a szubjektív jóléthez, így az egészség újratermeléséhez is (Molnár, 2019; Bartha, 2019; Müller et al., 2019a, Laoues et al., 2019, Lengyel et al., 2019).

A fitnesztermi szolgáltatások iránt megjelenő és egyre növekvő keresletről, a növekvő piaci részesedésről európai szintű kutatások is beszámolnak. Az európai fitneszpiac növekedését igazolja, hogy a fitneszklubok száma 2018-ban 3,2\%-kal, míg 2019-ben 4,6\%-kal nőtt az előző évhez képest (Deloitte, 2018, 2019). A kínálat növekedését a kereslet növekedése indukálta, hiszen 2018-ban már 60 millió, 2019-ben pedig 62,2 millió fö volt a fitnesztagsággal rendelkezők száma, mely 4\%-os, illetve 3,5\%-os keresletbővülést jelent az előző évhez képest (Deloitte, 2018, 2019). Vagyis egy év leforgása alatt az európai lakosság körében 2,2 millió fôvel nőtt azok száma, akik fitneszszolgáltatást vettek igénybe. Mindezek alátámasztják a szabadidősportok között a fitnesz térnyerését, erősödését.

A trendek folyamatos figyelése, a változások nyomon követése és az azokra történő reagálás a sport- és szabadidő-gazdaság területén müködő kis- és közepes vállalkozásoknak (kkv) elengedhetetlenül fontos, hiszen a fogyasztók igényeit a szolgáltatók így tudják a lehető legjobban kielégíteni, mellyel növekvő vendégelégedettséget érhetnek el (Müller, 2009). A fitnesztermi kereslet alakulásával kapcsolatos kutatások eredményei szerint a funkcionális tréningek a legnépszerübbek, melyek alkalmasak olyan edzés megvalósítására, mely a mindennapokban használt izmokat erősíti, támogatva ezzel a munkaképesség megőrzését és az életminőség javítását, ezt hazai kutatások is alátámasztják (Bujdosó-Remenyik, 2008, Dávid et al., 2008).

\section{A marketingmix elemei (4P) a fitneszszektorban}

A trendekhez igazított kínálatfejlesztés, azaz termék/szolgáltatás (product) -fejlesztés a szolgáltatók marketing-tevékenységének (egyben a marketingmixnek) egyik meghatározó eleme. A fitneszszolgáltatók számára kínálatuk kialakításakor kiemelten fontos figyelembe venni a vállalkozás által azonosított célcsoport(ok) igényeit. Ebben segíthet a motivációkutatás (Fehér et al., 2019a, 2019b, 2019c), valamint a kereslet elemzése (Bácsné et al, 2018a). Ezek a módszerek segítenek feltárni a nemek, életkorok szerint eltérő potenciális fogyasztók elvárásait.

A nők inkább a csoportos órákat (aerobic, fit-ball, callanetics, jóga stb.), míg a férfiak az egyéni, fitnesztermi gépek (erősitő és kardiogépek) használatával vagy személyi edző irányításával történő edzéseket részesítik előnyben (Alexandris et al., 2001; Lenténé et al., 2018b; Müller et al., 2019b.). A fiatalabb célcsoport esetében az alakformálás, a testszobrászat, míg az idősebbeknél az egészséget támogató (elsődlegesen nyújtó és keringésfokozó) elemeket tartalmazó, ízületkímélő foglalkozások iránt nő a kereslet. 
Hazai és nemzetközi kutatások igazolják a szabadidős sport kínálatában a minőség fontosságát (Bujdosó et al, 2015; Hidvégi et al., 2019; Bácsné et al., 2018a, 2018b; Boda, 2018; Dénes, 2015; Martínez et al.2010; Réthi et al., 2014; Yu et al., 2014; Lagrosen- Lagrosen, 2007; Dhurup et al., 2006; Lam et al., 2005; Hetesi, 2003; Papp-Rózsa, 2003; Alexandris et al., 2001).

A szolgáltatások minőségét az alap- és kiegészítő szolgáltatások megléte és azok minőségi aspektusai határozzák meg a jövőben, nemcsak a fitnesz-, de az egész szolgáltatási piacon (Bartha et al., 2018; Gottfried, 2019). Több kutatás ismerteti, hogy az edző vagy személyi edző személye igen nagyban befolyásolja a vendégek szolgáltatók közti választását, és meghatározó szerepe van a lojalitás elmélyítésében, valamint a vendégelégedettség alakulásában (Bartha, 2016; Pucsok et al., 2019a; UngváriFritz, 2014).

Az árképzés (price) egyfajta rejtett vagy passzív kommunikációs lehetőségként is felfogható a vevő és szolgáltató között, hiszen a termék vagy szolgáltatás ára alkalmas lehet a minőség üzenetének közvetítésére is a vevő irányába. A magasabb ár esetében a vevő általában egy magasabb minőséget társít a termékhez vagy szolgáltatáshoz. Így a megfelelő árképzés, amely a marketingmix fontos eleme, egyben a vállalkozás üzleti eredményességéhez is hozzájárulhat. Az ár meghatározásánál többféle módszer létezik, például: (1) költségalapú, (2) versenytársalapú, (3) értékalapú (Rekettye, 2004) és új termékek bevezetésénél beszélhetünk (1) lefölöző, (2) behatoló vagy (3) semleges árstratégiákról (Dean, 1976 in: Rekettye-Hetesi, 2009). Az előzőek közül a leginkább marketingszemléletű, a fogyasztók igényeire fókuszáló módszer az értékalapú árképzés, melynél az ármeghatározás során a vevők értékítéletét próbálják vizsgálni.

Fontos tekintettel lenni arra, hogy a vásárlók az ár-érték vagy árszolgáltatás arányt mérlegelik a vásárlási döntés meghozatalában. A hazai fitnesztermi kutatások mellett külföldi források is igazolják, hogy a szolgáltatás ára, ár-érték aránya a létesítményválasztást nagyban befolyásolja (de Barros - Gonçalves, 2009; Suwono-Sihombing, 2016; Jang-Choi, 2018; Bartha et al., 2018; Pucsok et al., 2019b).

Az értékesitési rendszer (place) szervezésének alapfilozófiája a fogyasztók felé az értékközvetítés és az értéknövelés, valamint a termékek, szolgáltatások könnyü és gyors elérhetőségének követelménye (Vágási, 2007). Az értékesítési út a kínált termékek és szolgáltatások hozzáféréséhez kapcsolódó elem, mely a fogyasztói igények minél teljesebb, magasabb színvonalon történő kielégítését szolgálja (Bauer-Berács, 2006; Kotler-Armstrong, 2014). Adott vállalkozásnál eltérő lehet az értékesítés helyszíne annak nagyságától függően (városi, regionális, országos vagy akár nemzetközi) vagy éppen az értékesítési csatorna tekintetében is. Utóbbinál a direkt, helyszíni értékesítés mellett megjelenhet az internetes (online) csatornákon történő értékesítés is, jellemzően elsődlegesen a kiegészítő termékek forgalmazása esetében. Ide kapcsolódhat még például a választék megfelelő kialakítása is, amely magában foglalhatja a különböző jegyek, bérletek, csomagok kialakítását a fogyasztói igényeknek megfelelően. 
A fitnesztermek szolgáltatása direkt, helyszíni szolgáltatásnak minősül. A sporttevékenységek helyszínéhez kapcsolódóan számos kutatás kimutatta, hogy maga a létesítmény (Greenwell et al., 2002; Wakefield-Blodgett, 1999; Zhang et al., 1998; Wakefield-Sloan, 1995) jelentősen befolyásolja az ügyfelek viselkedését. A jól megtervezett fizikai környezet akár ellensúlyozhatja is egy szerényebb szolgáltatás keltette negatív érzéseket (Wakefield-Blodgett, 1999). A sportlétesítményekhez kapcsolódó korábbi kutatásokban leggyakrabban a parkolási és étkezési lehetőségek biztosítása, a tisztaság, és a zsúfoltság (Wakefield-Sloan, 1995) jelent meg vevői elégedettséget befolyásoló tényezőként. A magyar fitneszfogyasztók edzésük helyszínéül szolgáló fitneszlétesítmény-választási döntéseit egy 2018-as felmérés szerint szintén az edzőterem tisztasága és felszereltsége, valamint az öltözők és mosdók tisztasága határozza meg (Bartha-Bácsné, 2018).

A vállalatok, szolgáltatók marketingkommunikációs politikájuk keretében meghatározzák mindazokat a tevékenységeket és eszközöket, melyek révén a célközönséget közvetlenül vagy közvetve befolyásolják termékeik, szolgáltatásaik vásárlása érdekében (promóciólpromotion). A célcsoport(ok) meghatározását követően fontos annak meghatározása, hogy milyen üzenetet fogalmazzon meg a szolgáltató a fogyasztók irányába, amellyel minél hatékonyabb módon képes őket megszólítani. Szükséges megtervezni továbbá a marketingkommunikációs csatornát, amelyen keresztül lehetőleg költséghatékony módon elérhetők a fogyasztók (Kiss, 2004). Ezenkívül fontos feladat a reklámkampányok, hirdetések minőségi és mennyiségi részleteinek, gyakoriságának és ütemezésének összeállítása. Ezekre a célokra a sportszolgáltatók, így fitnesztermek esetében is a lehetőségek széles köre ismert, a direktmarketingtől kezdve az értékesítési promóciókon keresztül a PR-tevékenységig és reklámozásig.

A kommunikációs eszközök fejlődése nagyrészt a technológiai fejlődéssel függ össze. A hagyományos médiumok (nyomtatott sajtó, rádió, telefon, televízió) mellett új médiumok jelentek meg, melyek elősegítik, hogy a kommunikáció gyorsabb, jobban a célcsoportra igazított vagy személyesebb legyen (Dajnoki, 2004, 2007a, 2007b; Vágási, 2007; Dajnoki et al, 2008; Dajnoki, 2010a). Napjainkban jellemző tendencia a modern csatornák, elsősorban az internet és azon belül is a közösségi média térnyerése, melyen keresztül jelentős mértékủ vásárlásösztönzés valósulhat meg, hiszen a fogyasztók leginkább az online térben gyűjtenek információt a termékekről, szolgáltatásokról és online térben vásárolnak (Ráthonyi, 2013, Ráthonyi et al., 2016; Fehér, 2018, Fehér-Szakály, 2018; Tütünkov-Hrisztov, 2019). Jó lehetőséget nyújtanak a megjelenésre a különböző közösségisport- és szabadidős rendezvények, illetve sportfesztiválok is (Dajnoki, 2010b; Fenyves et al., 2020). Nagy et al. (2018) tanulmányában az élsportolók személyes márkájában rejlő marketing lehetőségekre hívja fel a figyelmet. 


\section{Anyag és módszer}

Kutatásunk során 31, az Észak-Alföld régióban működő fitneszteremre kiterjedő primer kutatást végeztünk, mérőeszközünk kérdőív volt, amelyet strukturált szakértői interjúval egészítettünk ki. A szervezeti adatok (a szervezet telephelye, fó- és kiegészítő tevékenységi köre, gazdasági beszámoló főbb adatai, létszámadatok) megkérdezése után a szolgáltatók működésével, a szolgáltatások minőségi és mennyiségi aspektusaival, fejlesztési koncepciójukkal kapcsolatos kérdéseket tettünk fel. Jelen tanulmányban a megkérdezett szervezetek marketing tevékenységét jellemző marketingmix 4P-jével összefüggő vizsgálatok eredményeit ismertetjük. Ezeket párhuzamba állítottuk a hazai és nemzetközi fitnesztrendekkel. Következtetéseinkben megjelöljük a napjainkban a fitnesztrendeket leginkább meghatározó tényezőket és a sikeres és eredményes működéshez szükséges jövőbeli elvárásokat.

\section{Eredmények és azok értékelése}

Eredményeinket a korábbiakban alkalmazott felosztás szerint ismertetjük, a marketingmix 4P (termék, ár, értékesítés, promóció) -tényezői alapján.

\section{Termék}

A termékpolitikával kapcsolatos kérdések eredményei azt mutatják, hogy a szolgáltatók a fejlesztések minőségi aspektusait vélik a legfontosabbnak (átlag = 4,34, sd = 0,998). A legmagasabb átlagértéke, és a legkisebb szórása is ennek a tényezőnek volt, vagyis a szolgáltatók válaszai ebben mutatkoztak a legegységesebbnek (1. ábra). A strukturált szakértői interjúk válaszai alapján a minőségi aspektus fontosságát a szolgáltatóknál a hazai és a nemzetközi keresletnek megfelelő szolgáltatások megjelenése is tükrözi, amely csoportos órák, kardio-, valamint izomerősítő jellegü géppark müködtetését jelenti (Müller et al., 2019b). 


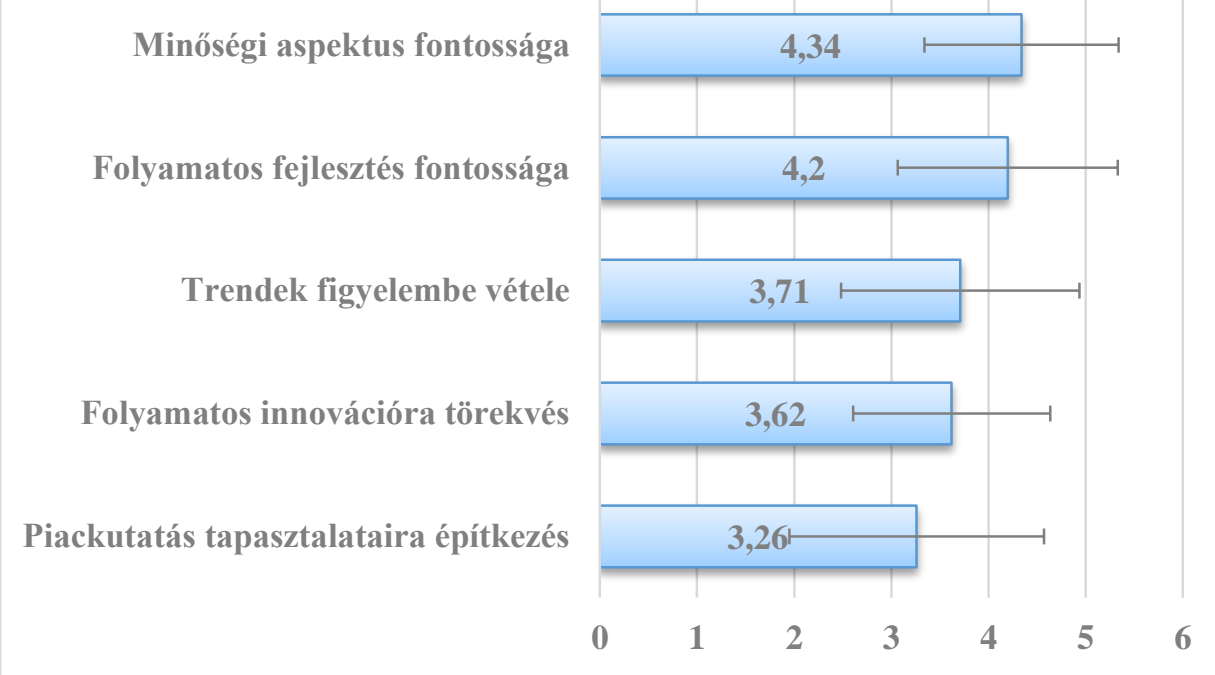

1. ábra: A termék/szolgáltatásfejlesztés tényezőinek fontossági sorrendje (átlag és szórás)

Forrás: saját adatgyüjtés és szerkesztés

A szolgáltatás minőségét több tényező is befolyásolja, amit a szakirodalmi kutatások is alátámasztanak: a minőség jelentheti képzett szakemberek alkalmazását, korszerű fitnesztermi gépek biztosítását (Torkos, 2009), különféle kiegészítő szolgáltatások meglétét (Gottfried 2019) és egyéb tényezőket is, melyek hozzájárulnak a vendégek igényeinek minél magasabb szinten történő kielégítéséhez (Bácsné Bába et al., 2018b; Bíró et al., 2019a, 2019b).

Sorrendben a következő tényező a folyamatos termék- és szolgáltatásfejlesztés, melyet a szolgáltatók szintén prioritásként kezelnek, hiszen elengedhetetlen a folyamatosan formálódó igényeknek és elvárásoknak való megfeleléshez, valamint a szolgáltatás színvonalának megtartásához. A termékfejlesztésnél a válaszadó sportszolgáltatók fontosnak ítélték meg a trendek folyamatos követését, mely egyértelmüen a szolgáltatásfejlesztés alapját jelenti.

Az innovációra való törekvés (átlag = 3,62, sd =1,015), habár az előző tényezőkhöz képest alacsonyabb mértékben, szintén megjelent a fitneszipar szolgáltatóinál, mely - ahogy Mórik et al. (2019) is megfogalmazza - elengedhetetlen a versenyképesség közép- és hosszú távú megőrzéséhez.

Megkérdezésünk alapján a piackutatás tapasztalatainak termékfejlesztésbe történő beépítése az utolsó a rangsorban. Ennek valószínüsíthető okaként jelölhető meg az erre a célra felhasználható források és/vagy szakemberek hiánya, emellett a trendek 
figyelése és a trendkutatások eredményeinek követése részben már elörevetíti a fogyasztói szokásokat is a jövőre vonatkozóan.

Az általunk vizsgált sportszolgáltatók kínálatuk kialakításakor az alapszolgáltatások mellett megcélozzák az olyan kiegészítő szolgáltatásokat is, mint például a wellnesskínálati elemek és azok fejlesztése. Ezek a szolgáltatások (pl. masszázs, szauna) jól kiegészítik a különböző edzésformákat, mivel ezáltal hatékony módon érhető el a terhelésből fakadó izomgörcsök, kontraktúrák oldása, és a laza, elasztikus izomzat kialakítása. Így ezen szolgáltatások egyben biztosítják a regenerációt és a stresszoldást is. A szolgáltatásfejlesztésben a változó igényeknek való megfelelés mellett több esetben megjelenik az egyediségre való törekvés (pl. falmászásra alkalmas terem, TRXterem kialakítása), amely piaci előnyt jelenthet, ezáltal hozzájárulva a versenyképesség megőrzéséhez vagy javításához.

\section{Ár}

Az árpolitika alkalmazásában a szolgáltató vállalkozások esetenként ármeghatározó, jellemzően azonban árelfogadó stratégiát követnek, és termékeik, szolgáltatásaik árát a piaci körülményekhez alakítják, figyelemmel vannak a versenytársak által szabott árakra. Lefölöző stratégia alkalmazása a magyar fogyasztók árérzékenysége miatt általában nem célravezető, csupán azoknál a szolgáltatóknál, akik valamilyen termékvagy szolgáltatásjellemző alapján monopolhelyzetűnek mondhatók (pl. belvárosi fekvésű, exkluzív gépekkel felszerelt, nagy alapterületű látványterem, sok kiegészítő szolgáltatással). Behatoló árpolitika alkalmazása az újonnan piacra lépő szolgáltatók esetében jellemző, piacszerzési céllal. Az adott fitneszszolgáltató külső és belső környezetét, tényezőit figyelembe vevő, megfelelő árképzési stratégia kiválasztása döntő fontosságú a versenyképesség tartós megőrzésében.

\section{Értékesités}

Az értékesítés helye esetében a helyi igények kielégítése (átlag $=4,68, \mathrm{sd}=0,535$ ) kapta a legmagasabb értéket a megkérdezett fitnesztermek működtetőitől (2. ábra). Ez alapján a szolgáltatók leginkább a helyi lakosok igényeinek kiszolgálására fókuszálnak, ami a földrajzi adottságokból következik. A regionális és országos igények mellett a nemzetközi igények kielégítése kisebb szerepet kap. Habár a külföldiek (turisták és egyetemi hallgatók) célcsoportja - főként a megyeszékhelyen - az utóbbi időben növekedést mutat, a régióba érkező turistáknál figyelembe kell venni, hogy a szállodák saját szabadidős kínálattal, gyakran saját fitneszteremmel is rendelkeznek 
(Lenténé et al., 2019; Müller, 2018; Fenyves et al., 2014; Kerényi et al., 2009;). A külföldről érkező egyetemi hallgatók pedig, mint fogyasztók, csupán néhány nagyobb fitneszterem esetében jelennek meg.

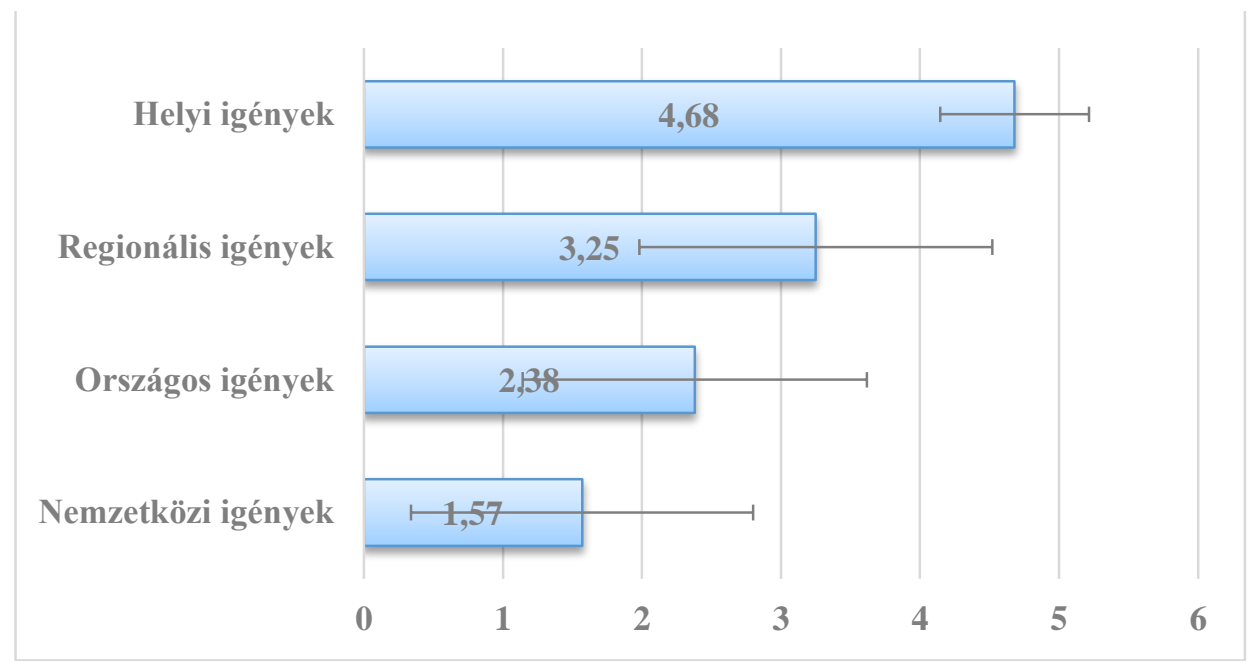

2. ábra: A célcsoport meghatározása, területi/földrajzi szempontból (átlag és szórás)

Forrás: saját adatgyüjtés és szerkesztés

\section{Promóció}

A promócióval, reklámozással kapcsolatos kérdésekre adott válaszok alapján a hagyományos marketingkommunikációs eszközök mellett a szolgáltatók már a nem hagyományos eszközöket (online megjelenés, közösségi médiák stb.) is alkalmazzák, sőt előnyben részesítik. Mindez megfelel napjaink trendjeinek, miszerint a lakosság számára szolgáltatásokat nyújtó vállalkozások egyre inkább nyitnak a modern hirdetési felületek irányába, mint például az online felületek és közösségi média, melynek szerepe napjainkban a sportban is erősödni látszik (Gősi-Zsíros, 2011). Az online marketingkommunikációs eszközök használata egyértelműen hozzájárulhat a szolgáltatók versenyképességének növeléséhez (Fehér, 2017; Gáti et. al., 2019).

\section{Következtetések, javaslatok}

Az Észak-Alföld régió fitneszszolgáltatóinak vizsgálatából kiderül, hogy a termékfejlesztés során a szolgáltatás megfelelő minőségének biztosítását vélték a legfontosabb- 
nak, melyet a fejlesztés folyamatossága és a trendek figyelembe vétele követett. A folyamatosan változó társadalmi jellemzőknek, körülményeknek megfelelően a fogyasztói igények is változnak a fitneszszolgáltatások iránt, melyekre a szolgáltatóknak figyelemmel kell lenni a termékfejlesztés során a versenyképességük megőrzése érdekében. Az edzésmódszerek és edzéseszközök változását, illetve az új típusú mozgásformák iránt megjelenő igényt a fitneszszolgáltatók a csoportos órák kínálatával és a kardio-, valamint izomerősítő jellegű géppark fejlesztésével biztosítják (Müller et al., 2019b), melyet korábbi cikkünkben ismertettünk. Az általunk vizsgált sportszolgáltatók kínálatuk kialakításakor az alapszolgáltatások mellett kiegészítő wellnesskínálati elemeket is biztosítanak, amelyek jól kiegészítik a különböző edzésformákat, biztosítják a regenerációt és a stresszoldást is. A szolgáltatásfejlesztésben megjelenik az egyediségre való törekvés, amely piaci előnyt jelenthet, ezáltal hozzájárulva a versenyképesség megőrzéséhez vagy javításához.

A szolgáltatók árképzésére az árelfogadó stratégia, illetve a versenytársakhoz igazított árképzés a leginkább jellemző, célcsoportjukat tekintve pedig leginkább a helyi lakossági igények kielégítését célozzák meg. Mindezeket figyelembe véve történik az értékesítési utak tervezése.

A fitneszszolgáltatók promóciós tevékenysége kapcsán megállapítható, hogy a hagyományos marketingkommunikációs eszközökkel szemben - a célcsoport jellemzöiből is adódóan - előnyben részesítik az online marketing lehetőségeit, mely egyrészt költséghatékony, rugalmas, emellett a modern fogyasztói trendeket követi.

\section{Köszönetnyilvánítás}

A publikáció elkészítését a „GINOP-2.3.2-15-2016-00062 Életminőség fejlesztése Kelet-Magyarországon: Táplálkozás-, teljesítménybiológiai és biotechnológiai experimentális kutatások és eszközfejlesztések a humán megbetegedések megelőzésére és kezelésére" projekt támogatta.

\section{Hivatkozott források}

[1.] Alexandris, K. - Dimitriadis, N. - Kasiara, A. (2001): The behavioural consequences of perceived service quality: An exploratory study in the context of private fitness clubs in Greece. European Sport Management Quarterly, 1. évf. 4. sz. 280-299. o.

DOI: $\underline{10.1080 / 16184740108721903}$ 
[2.] Bácsné Bába É. - Balogh R. - Bács Z. - Fenyves V. - Dajnoki K. (2018a): Sportszolgáltatások keresleti, kínálati oldalának elemzési lehetőségei. Studia Mundi - Economica, Vol. 5. No. 3. 19-33.

DOI: $10.18531 /$ Studia.Mundi.2018.05.03.19-33

[3.] Bácsné Bába, É. - Pfau, C. - Dajnoki, K. - Müller, A. (2018b): Examining the quality parameters of sports services. In: Šimonek, J. - Dobay B. (Eds.): Sport science in motion: proceedings from the scientific conference. Komárno, Univerzita J. Selyeho, 236-243. o.

[4.] Bartha É. J. (2016): Szakmai kompetenciák és képzettség szerepe az edzői munka hatékonyságában. Taylor: Gazdálkodás- és Szervezéstudományi Folyóirat: A Virtuális Intézet Közép-Európa Kutatására Közleményei, 8. évf. 4. sz. 35-44. o.

[5.] Bartha É. J. - Müller A. - Bácsné Bába É. (2018): A fitnesz fogyasztók sportlétesítmény-választását befolyásoló legfőbb szempontok alakulása életkor szerint. Selye E-Studies, 9. évf. 1. sz. 4-12. o.

[6.] Bartha É. J. (2019): Fitnesz vendégek sportfogyasztási szokásai. KözépEurópai Közlemények, 12. évf. 2. sz. 149-161. o.

[7.] Bauer A. - Berács J. (2006): Marketing. Budapest, Magyarország, Aula Kiadó, 658. o.

[8.] Bíró M. - Müller A. (2017): Aktív pihenés, rekreáció. In: Dobos, A. - Mika, J. (szerk.): Természeti és kultuirtörténeti értékek Eger térségében. Eger, Líceum Kiadó. 128-130. o.

[9.] Bíró, M. - Molnár, A. - Hídvégi, P. - Mikhárdi, S. - Pucsok, J. M. Lenténé Puskás, A. (2019a): The role of massage in tourism, and the hotels offerings in Hungary. In: Šimonek, J. - Dobay B. (szerk.): Sport science in motion: Proceedings from the scientific conference. Komárno, Univerzita J. Selyeho v Komárne. 27-36. o.

[10.] Bíró M. - Pucsok J. M. - Hidvégi P. - Molnár A. - Mikhárdi S. - Lenténé Puskás A. (2019b): A magyarországi és az Észak-alföldi fürdők jellemzőinek, forgalmának és a fürdők által nyújtott szolgáltatásoknak az elemzése. In: Balogh L. (szerk.): Sport és társadalom. Debrecen, Debreceni Egyetem Sporttudományi Koordinációs Intézet. 18-28. o.

[11.] Boda, E. J. (2018): Examination of Adventure park consumers in therm of motivations and amount of leisure time. Acta Oeconomica Universitas Selye, 7. évf. 2. sz. 33-46. o.

[12.] Bujdosó Z - Remenyik B. (2008): A hazai turisták életminőségének a feltérképezése az Észak-Magyarország Régióban In: Dávid L. (szerk.) A turizmus szerepe az Észak-Magyarország Régióban I-II Gyöngyös, Károly Róbert Főiskola, 40-48. o. 
[13.] Bujdosó, Z. - Dávid, L. - Varga, D. - Pénzes, J. - Gyurkó, Á. - Zhakupov, A. (2015): Tourism Development And Cross-Border Cooperation in the Hungarian-Romanian Border Region. Geojournal of Tourism and Geosites, Vol. 16. No. 2. 153-163.

[14.] Dajnoki K. (2004): Fejlesztési lehetőségek a szakmai kommunikáció területén. IX. Nemzetközi Agrárökonómiai Tudományos Napok, Gyöngyös, [CD kiadvány].

[15.] Dajnoki, K. - Berde, Cs. - Szabados, Gy (2008): Analysis of professional communication in the agriculture in Hungary. In: Česká, zemědělská univerzita (szerk.) Agrarian Perspectives; XVII.: Challenges for the 21th century. Prague, Csehország: Czech University of Agriculture in Prague, 215222. p.

[16.] Dajnoki, K. (2007a): Analysis of influential factors in organizational communication. In: Agrarian Perspectives XVI. „European Trends in the Development of Agriculture and Rural Areas" International Scientific Conference. Prague, Csehország: Česká Zemědělská Univerzita, 1363-1371. p.

[17.] Dajnoki, K. (2007b): Time value analysis of leader communication. In: Ferencz, Árpád (ed.) Erdei Ferenc IVth Scientific Conference, Kecskemét, 41-47.p.

[18.] Dajnoki K. (2010a): Kommunikáció az esélyegyenlőségi emberi erőforrás menedzsmentben. In: Jelenkori Társadalmi és Gazdasági Folyamatok, 5. évf. 1-2. sz. 65-70. o.

[19.] Dajnoki K. (2010b): A debreceni Utazás és Szabadidő Idegenforgalmi Kiállítás és Vásár szervezési tapasztalatai. „International Conference on Tourism and Sports Management" Nemzetközi Konferencia, Debrecen. [CD kiadvány].

[20.] Dávid, L. - Bujdosó, Z. - Tóth, G. (2008): Tourism planning in the HajdúBihar - Bihor Euroregion In: Süli-Zakar, I. (szerk.) Neighbours and partners : on the two sides of the border Debrecen, Kossuth Egyetemi Kiadó, 323-332.

[21.] Dean, J. (1976): Pricing Policies for New Products. Harvard Business Review. 141-153. p.

[22.] de Barros, C. - Gonçalves, L. (2009): Investigating individual satisfaction in health and fitness training centres. International Journal of Sport Management and Marketing, Vol. 5. No. 4. 384-395. p. DOI: 10.1504/IJSMM.2009.023367

[23.] Deloitte (2018): European Health \& Fitness Market Report 2018. Letöltés dátuma: 2020. december 10, forrás: Deloitte: 
https://www2.deloitte.com/content/dam/Deloitte/de/Documents/consumerbusiness/European\%20Health\%20and\%20Fitness\%20Report_2018_extract. pdf.

[24.] Deloitte (2019): European Health \& Fitness Market Report 2019. Letöltés dátuma: 2020. december 10, forrás: Deloitte:

https:/www2.deloitte.com/content/dam/Deloitte/de/Documents/consum er-business/EuropeActive_Deloitte_EHFMR\%202019_DE.pdf

[25.] Dénes F. (2015): Sportszolgáltatások menedzsmentje. Szöveggyüjtemény. Debrecen, Campus Kiadó. 132 o.

[26.] Dhurup, M. - Singh, P. C. - Surujlal, J. (2006): Customer service quality at commercial health and fitness centres. South African Journal for Research in Sport, Physical Education and Recreation, Vol. 28. No. 2. 39-54. p. DOI: 10.4314/sajrs.v28i2.25942

[27.] Eurobarometer (2018): Special Eurobarometer 472, Sport and physical activity. Letöltés dátuma: 2020. december 10, forrás: Európai Unió: https://data.europa.eu/euodp/en/data/dataset/S2164_88_4_472_ENG

[28.] Fehér A. (2017): Online marketingkommunikáció. In: Szakály Z. (szerk.): Élelmiszer-marketing. Budapest, Akadémiai Kiadó. 381-393. o.

[29.] Fehér A. (2018): A digitális élelmiszer-fogyasztó jellemzői. Közép-Európai Közlemények, 11. évf. 42. sz. 93-104. o.

[30.] Fehér A. - Bácsné Bába É. - Müller A. - Szakály Z. (2019a): MPAM-R modellekkel kapcsolatos kutatások rendszerezése - Szakirodalmi áttekintés. In: Fehér A. - Szakály Z. (szerk.): Egészségpiaci kutatások. Debrecen, Debreceni Egyetem Gazdaságtudományi Kar. 173-183. o.

[31.] Fehér A. - Bácsné Bába É. - Müller A. - Szakály Z. (2019b): Fizikai aktivitás motivációival kapcsolatos modellek rendszerezése II. Szakirodalmi áttekintés. In: Fehér A. - Szakály Z. (szerk.): Egészségpiaci kutatások. Debrecen, Debreceni Egyetem Gazdaságtudományi Kar. 164172. o.

[32.] Fehér A. - Bácsné Bába É. - Müller A. - Szakály Z. (2019c): Fizikai aktivitás motivációival kapcsolatos modellek rendszerezése I. - Szakirodalmi áttekintés. In: Fehér, A. - Szakály, Z. (szerk.): Egészségpiaci kutatások. Debrecen, Debreceni Egyetem Gazdaságtudományi Kar. 152-163. o.

[33.] Fehér A. - Szakály Z. (2018): A hazai tejszektor online marketing lehetőségei. Tejgazdaság : Tudomány és Gyakorlat. 75. évf. 1. sz. 55-65. o.

[34.] Fenyves V. - Bácsné Bába É. - Nagy A. (2020): Közösségben jobb sportolni! A debreceni Campus Sportfesztivál résztvevőinek vizsgálata. Debreceni Szemle. 43. évf. 1. sz. 112-126. o.

[35.] Fenyves V. - Dékán Tamásné Orbán I. - Könyves E. - Nagy A. - Sándor F. (2014): Economical aspects of thermal and medical tourism. APSTRACT 
- Applied Studies in Agribusiness and Commerce, Vol. 8. No. 4. sz. 77-84. p. DOI: 10.19041/APSTRACT/2014/4/12

[36.] Gáti M. - Csordás T. - Piskóti M. (2019): Kis- és közepes vállalatok marketingcélú közösségimédia-használatának megfigyelése online környezetben - Módszertani megközelítés a tisztánlátás fényében. In: Veres Z. - Sasné Grósz A. - Liska F. (szerk.): Ismerjük a vevőt?: A vásárlás pszichológiája: Az Egyesület a Marketingoktatásért és Kutatásért XXV. Országos konferenciájának elöadásai. Veszprém, Pannon Egyetem. 730-738. o.

[37.] Gottfried P. (2019): A részvételi sportszolgáltatás vizsgálata a G4 2.0 edzőterem példáján keresztül. In: Balogh L. (szerk.): Sokoldalú sporttudomány. Debrecen, Debreceni Egyetem Sporttudományi Koordinációs Intézet, 29-40. o.

[38.] Gődény N. - Biró M. - Lenténé Puskás A. - Lente L. - Müller A. (2018): A fogyasztói szokások és trendek változásának vizsgálata a fitnesz területén. In: Balogh L. (szerk.) Fókuszban az egészség. Debrecen, Magyarország, Debreceni Egyetem Sporttudományi Koordinációs Intézet. 9-18. o.

[39.] Gősi Zs. - Zsiros M. (2011): Sport a közösségi médiában. Magyar Sporttudományi Szemle, 12. évf. 1. sz., 4-10. o.

[40.] Greenwell, C. T. - Fink, J. S. - Pastore, D. L. (2002): Assessing the Influence of the Physical Sports Facility on Customer Satisfaction within the Context of the Service Experience. Sport Management Review, Vol. 5. 129-148. o. DOI: $10.1016 / S 1441-3523(02) 70064-8$

[41.] Hetenyi, G. - Lengyel, A. D. - Szilasi, M. D. (2019): Quantitative analysis of qualitative data: Using voyant tools to investigate the sales-marketing interface. Journal of Industrial Engineering and Management, Vol. 12. No. 3. 393-404. p. DOI: $10.3926 /$ jiem.2929

[42.] Hetesi E. (2003): A minőség, az elégedettség és a lojalitás mérésének problémái a szolgáltatásoknál, és azok hatása a jövedelmezőségre. Marketing \& Menedzsment, 37. évf. 5. sz. 42-50. o.

[43.] Hidvégi, P. - Biró, M. - Lenténé Puskás, A. - Tatár, A. - Bárdos, K. Pucsok, J. M. (2019): Quality of Wellness Services in the North Great Plain Region. Stadium - Hungarian Journal of Sport Sciences, Vol. 2. No. 1. 1-11. p. DOI: $10.36439 /$ SHJS/2019/1/2928

[44.] Horkay, B. - Lenténé Puskás, A. - Biró, M. (2018): The supply elements and the recreational possibilities in the city and in the countryside. In: Šimonek, J. - Dobay, B. (szerk.) Sport science in motion: Proceedings from the scientific conference. Komárno, Univerzita J. Selyeho. 330-339. p.

[45.] Jang, W. Y. - Choi, K. (2018): Factors influencing choice when enrolling at a fitness center. Social Behavior and Personality: an International Journal, Vol. 46. No. 6. 1043-1056. p. DOI: 10.2224/sbp.7104 
[46.] Kerényi, E. - Müller, A. - Szábó, R. - Mosonyi, A. (2009): Analysis of Agárd, Komárom and Papa's Thermal and Experiences bath according the guest's satisfaction. In: Egészségügyi marketing és telekommunikáció címü konferencia kiadványkötete. Mátrai Gyógyintézet. Magyarország, Kékestető. 56-67. o.

[47.] Kiss M. (2004): Marketing. Budapest, Független Pedagógiai Intézet. 578 o.

[48.] Kotler, P. - Armstrong, G. (2014): Principles of Marketing. Fifteenth Edition. Pearson Education Limited. 720. o.

[49.] Lagrosen, S. - Lagrosen, Y. (2007): Exploring service quality in the health and fitness industry. Managing service quality: an international journal, Vol. 17. No. 1. 41-53. p. DOI: 10.1108/09604520710720665

[50.] Lam, E. T. - Zhang, J. J. - Jensen, B. E. (2005): Service Quality Assessment Scale (SQAS): An instrument for evaluating service quality of health-fitness clubs. Measurement in physical education and exercise science, Vol. 9. No. 2. 79-111.p. DOI: $10.1207 /$ s15327841mpee0902_2

[51.] Laoues, N. - Dobay B. - Müller A. (2019): Examination of The Leisure Time-Related Consumption Habits of Young People With Disabilities With Special Emphasis on Sports. Selye E-Studies. Vol. 10. No. 2. 34-45. p.

[52.] Lengyel, A. (2016): Tourism, meditation, sutainability. APSTRACT Applied Studies in Agribusiness and Commerce, Vol. 10. No. 1. 81-91. p. DOI: $10.19041 / A P S T R A C T / 2016 / 1 / 11$

[53.] Lengyel, A. - Kovács, S. - Müller, A. - Lóránt, D. - Szőke, Sz. - Bácsné Bába, É. (2019): Sustainability and Subjective Well-Being: How Students Weigh Dimensions. Sustainability, Vol. 11. No. 23. Paper: 6627. DOI: $\underline{10.3390 / \text { su1 } 1236627}$

[54.] Lenténé Puskás A. - Biró M. - Dobay B. - Pucsok J. M. (2018b): A szabadidő sportolás kínálati elemeinek, és szolgáltatásainak vizsgálata Magyarország Észak-alföldi régiójának szállodáiban. Selye E-Studies, 9. évf. 1. sz. 13-21. o.

[55.] Lenténé Puskás A. - Tatár A. - Lente L. - Pucsok J. M. - Bíró M. - Hidvégi P. (2019): A sport és wellness elemek megjelenése az Észak-alföldi régió három-, négy- és ötcsillagos szállodáinak kínálatában. In: Bácsné Bába É. Müller A. (szerk.): „Mozgással az egészségért” A fizikai aktivitás jelentösége a jövö munkavállalóinak egészségmegörzésében: Nemzetközi Konferencia és Workshop: Válogatott tanulmánykötet. Debrecen, Debreceni Egyetem, 204215. o.

[56.] Lenténé P. A. - Hidvégi P. - Tatár A. - Pucsok J. M. - Biró M. (2018a): Recreational potential of the northern great plain region in Hungary. In: Šmonek, J. - Dobay B. (szerk.) Sport science in motion: Proceedings from the scientific conference. Komárno, Univerzita J. Selyeho. 218-226. p. 
[57.] Martínez, J. A. - Ko, Y. J. - Martínez, L. (2010): An application of fuzzy logic to service quality research: a case of fitness service. Journal of Sport Management, Vol. 24. No. 5. 502-523. p. DOI: 10.1123/jsm.24.5.502

[58.] Molnár A. (2019): Fitnesz trendek az egészség szolgálatában. In: Bácsné Bába É. - Müller, A. (szerk.) „Mozgással az egészségért" A fizikai aktivitás jelentösége a jövö munkavállalóinak egészségmegörzésében: Nemzetközi Konferencia és Workshop: Válogatott tanulmánykötet. Debreceni Egyetem, Debrecen, Magyarország. 113-120. o.

[59.] Mórik, K. V. - Bácsné Bába, É. - Müller, A. - Ráthonyi, G. - Molnár, A. (2019): The appearance of product innovation in the life of a Hungarian SMEs in the global market of sporting goods - implications from a research. Geosport for Society, Vol. 10. No. 1. 25-38. p.

DOI: $10.30892 /$ gss.1003-045

[60.] Müller A. (2009): A legújabb trendek a sportmarketing és menedzsment területén. In: Györfi, J. (szerk.): Sportszakember-továbbképzési konferenciasorozat. Budapest, Nemzeti Sportszövetség. 69-72. o.

[61.] Müller A. (2018): Health tourism in Hungary. In: Šimonek, J. - Dobay, B. (szerk.): Sport science in motion: proceedings from the scientific conference. Komárno, Univerzita J. Selyeho. 8-15. p.

[62.] Müller A. - Bácsné Bába É. - Gabnai Z. - Pfau C. - Pető K. (2019b): A fitnesztrendek és új típusú mozgásformák társadalmi és gazdasági aspektusai. Acta Carolus Robertus, 9. évf. 2. sz. 109-122. o. DOI: 10.33032/acr.2019.9.2.109

[63.] Müller A. - Lengyel A. - Koroknay Zs. - Molnár A. (2019a): Népszerű fitnesz mozgásformák. In: Bácsné Bába É. - Müller A. (szerk.): „Mozgással az egészségért" A fizikai aktivitás jelentösége a jövö munkavállalóinak egészségmegörzésében: Nemzetközi Konferencia és Workshop: Válogatott tanulmánykötet. Debrecen, Debreceni Egyetem, 106-112. o.

[64.] Nagy A. - Molnár D. - Szikszai-Németh K. (2018): A személyes márkaépítés kihívásai napjainkban. International Journal of Engineering and Management Sciences, 3. évf. 4. sz. 485-494. o.

[65.] Nagy A. - Tobak J. (2014): Lakossági sportolási és sportfogyasztási szokások vizsgálata. Magyar Sporttudományi Szemle, 15. évf. 2. sz. 47. o.

[66.] Nagy, A. - Tobak, J. (2015): The role of sport infrastructure: use, preferences and needs. APSTRACT - Applied Studies In Agribusiness and Commerce, No. 9. No. 1-2. 47-52. o.

DOI: $10.19041 /$ APSTRACT/2015/1-2/9

[67.] Papp K. - Rózsa A. (2003): Szolgáltatásminőség elméletben és gyakorlatban. Marketing \& menedzsment, 37. évf. 5. sz. 4-13. o. 
[68.] Pucsok J. M. - Lenténé Puskás A. - Hidvégi P. - Tatár A. - Bíró M. (2019a): Az Észak-alföldi régió fitnesztermeiben dolgozók képesítésének összehasonlító elemzése. In: Bácsné Bába É. - Müller A. (szerk.): „Mozgással az egészségért" A fizikai aktivitás jelentösége a jövö munkavállalóinak egészségmegörzésében: Nemzetközi Konferencia és Workshop: Válogatott tanulmánykötet Debrecen, Debreceni Egyetem, 198-203. o.

[69.] Pucsok J. M. - Bíró M. - Hidvégi P. - Lenténé Puskás A. - Tatár A. (2019b): Az Észak-alföldi és az Európai Alap és- középszintű sportszakember-képzés sajátosságainak összehasonlító vizsgálata. In: Balogh L. (szerk.): Sokoldalú sporttudomány. Debrecen, Debreceni Egyetem Sporttudományi Koordinációs Intézet, pp. 70-77.

[70.] Ráthonyi G. (2013): Influence of social media on tourism - especially among students of the University of Debrecen. APSTRACT - Applied Studies In Agribusiness and Commerce, Vol. 7. No. 1. 105-112. p. DOI: 10.19041/Apstract/2013/18

[71.] Ráthonyi, G. - Ráthonyi-Ódor, K. - Várallyai, L. - Botos, Sz. (2016): Influence of social media on holiday travel planning. Journal of Ecoagrotourism, Vol.12. No. 1.57-62. p.

[72.] Rekettye G. (2003): Az ár a marketingben. Budapest, Magyarország, KJKKerszöv, 342 o.

[73.] Rekettye G. - Hetesi E. (2009): Kinálatmenedzsment. Budapest, Akadémiai Kiadó, 276 o.

[74.] Réthi G. - Kása R. - Molnár L. (2014): A szolgáltatásminőség értelmezésének különbségei-percepcióvezérelt szolgáltatások minőségmodellje kialakításának első lépései. Prosperitas, 1. évf. 2. sz. 26-42. o.

[75.] Suwono, L. V. - Sihombing, S. O. (2016): Factors Affecting Customer Loyalty of Fitness Centers: An Empirical Study. Jurnal Dinamika Manajemen, Vol. 7. No. 1. sz. 45-55. o.

[76.] Thompson, W. R. (2016): Worldwide survey of fitness trends for 2017. ACSM's Health \& Fitness Journal, Vol. 20. No. 6. 8-17. p. DOI: 10.1249/FIT.0000000000000252

[77.] Thompson, W. R. (2017): Worldwide survey of fitness trends for 2018: the CREP edition. ACSM's Health \& Fitness Journal, Vol. 21. No. 6. 10-19. DOI: $10.1249 / F I T .0000000000000341$

[78.] Thompson, W. R. (2020): Worldwide survey of fitness trends for 2020. Letöltés dátuma: 2020. december 10, forrás: American College of Sports and Medicine. DOI: $10.1249 /$ FIT.0000000000000526

[79.] Torkos Z. (2009): A világ legjobb fitnesz gépeinek tervezése, az egészség megóvására összpontosítva, a Life Fitness budapesti tervező központjában. 
In: XIV. Fiatal Müszakiak Tudományos Ülésszaka. Kolozsvár, Románia. 221-224. o. DOI: $10.36243 / \mathrm{fmtu}-2009.55$

[80.] Tütünkov-Hrisztov, J. (2019): A turizmus közvetítő szektorának evolúciója és trendjei. In: Balogh L. (szerk.): Sport és társadalom. Debrecen, Debreceni Egyetem Sporttudományi Koordinációs Intézet, 125-137. o.

[81.] Ungvári M. - Fritz P. (2014): A személyi edző szerepe a teljes körü fitnesz elérésében $=$ The role of the certified personal trainer to achieve extensive fitness. Recreation, 4. évf. 3. sz. 22-26. p. DOI:

10.21486/recreation.2014.4.3.2

[82.] Vágási M. (2007): Marketing - stratégia és menedzsment. Budapest, Alinea Kiadó. 440 o.

[83.] Wakefield, K. L. - Sloan, H. J. (1995): The Effects of Team Loyalty and Selected Stadium Factors on Spectator Attendance. Journal of Sport Management, Vol. 9. No. 2. 153-172. p. DOI: 10.1123/jsm.9.2.153

[84.] Wakefield, K. L. - Blodgett, J. G. (1999): Customer response to intangible and tangibleservice factors. Psychology and Marketing, Vol. 16. 51-68. p.

[85.] Yu, H. S. - Zhang, J. J. - Kim, D. H. - Chen, K. K. - Henderson, C. Min, S. D. - Huang, H. (2014): Service quality, perceived value, customer satisfaction, and behavioral intention among fitness center members aged 60 years and over. Social Behavior and Personality: an international journal, Vol. 42. No. 5. 757-767. p. DOI: 10.2224/sbp.2014.42.5.757

[86.] Zhang, J. J. - Smith, D. W. - Pease, D. G. - Lam, E. T. C. (1998): Dimensions of spectatorsatisfaction toward support programs of professional hockey games. International Sports Journal, Vol. 2. No. 2. sz. 1-17. p.

\section{Szerzők}

\section{Dr. Müller Anetta}

Egyetemi docens

Debreceni Egyetem, Gazdaságtudományi Kar, Sportgazdasági és -Menedzsment Intézet

muller.anetta@econ.unideb.hu

\section{Dr. Gabnai Zoltán}

Tudományos segédmunkatárs

Debreceni Egyetem, Gazdaságtudományi Kar, Gazdálkodástudományi Intézet gabnai.zoltan@econ.unideb.hu 
Dr. Bácsné Prof. Dr. Bába Éva

Egyetemi tanár

Debreceni Egyetem, Gazdaságtudományi Kar, Sportgazdasági és -Menedzsment Intézet

bacsne.baba.eva@econ.unideb.hu

\section{Dr. Pfau Christa Sára}

Adjunktus

Debreceni Egyetem, Gazdaságtudományi Kar, Sportgazdasági és -Menedzsment Intézet

pfau.christa@econ.unideb.hu

\section{Dr. Bartha Éva Judit}

Tudományos segédmunkatárs

Debreceni Egyetem, Gazdaságtudományi Kar, Sportgazdasági és -Menedzsment Intézet

bartha.eva.judit@econ.unideb.hu

\section{Molnár Anikó}

Mesterszakos egyetemi hallgató

Debreceni Egyetem, Gazdaságtudományi Kar

miller.e.annie@gmail.com

\section{Prof. Dr. Pető Károly}

Egyetemi tanár

Debreceni Egyetem, Gazdaságtudományi Kar, Vidékfejlesztés, Regionális

Gazdaságtan és Turizmusmenedzsment Intézet

peto.karoly@econ.unideb.hu 